\title{
Cadherin-3 Staining Method
}

National Cancer Institute

\section{Source}

National Cancer Institute. Cadherin-3 Staining Method. NCI Thesaurus. Code C122855.

An immunohistochemical technique used to detect the presence of cadherin-3 (Pcadherin) in a tissue sample. 